\section{Nutrient Accumulation and Tipburn in NFT-grown Lettuce at Several Potassium and pH Levels}

\author{
Wlodzimierz Bres ${ }^{1}$ and Leslie A. Weston \\ Department of Horticulture and Landscape Architecture, University of \\ Kentucky, Lexington, KY 40546-0091
}

Additional index words. Lactuca sativa, hydroponics, growth, nutrient accumulation, nutrient film technique

\begin{abstract}
Buttercrunch', 'Grand Rapids', and 'Summer Bibb' lettuce (Lactuca sativa L.) seedlings were grown with the nutrient film technique (NIT). The influence of two $\mathrm{K}$ concentrations $\left(150\right.$ and $\left.225 \mathrm{mg}^{-1 i t e r}{ }^{-1}\right)$ and four solution $\mathrm{pH}$ levels $(5.0,5.5,6.0$, and 6.5) on lettuce tipburn was investigated in four experiments. Additionally, the influence of $\mathrm{pH}$ on foliar nutrient concentration was examined. Even though tipburn was observed in 'Buttercrunch' and 'Summer Bibb' lettuce, neither $\mathrm{K}$ nor $\mathbf{p H}$ level consistently affected tipburn incidence. No tipburn was observed in 'Grand Rapids'. Solution pH generally did not affect concentration of total $\mathrm{N}$ and $\mathrm{NO}_{3}-\mathrm{N}$ in lettuce tissue. Increasing the $\mathrm{pH}$ increased $\mathrm{K}$ concentration and resulted in increased proportions of $\mathrm{K}$ compared to $\mathrm{Mg}$ or $\mathrm{Ca}$. Although the influence of solution $\mathrm{pH}$ on $\mathrm{P}$, Ca, and Mg concentration was significant, nutrient accumulation differences were not reflected in lettuce fresh-weight differences. The influence of $\mathbf{K}$ solution concentration and $\mathrm{pH}$ on lettuce yield was not significant. Tipburn incidence in NIT-produced lettuce appears to be primarily affected by environmental conditions maintained during greenhouse growth.
\end{abstract}

Numerous investigations with field and greenhouse-grown lettuce have indicated the relationship between temperature, light intensity and duration, and relative humidity on tipburn, a Ca-related disorder that occurs under specific environmental conditions (Collier and Tibbitts, 1984; Schlagnhaufer et al., 1987; Tibbitts and Rao, 1966). Experiments conducted in the field sometimes suggest that factors involved in tipburn development are different from those determined to be critical in greenhouse production, particularly in NFT, where crop maintenance depends on nutrient solution properties. The solution properties that most affect hydroponically grown lettuce appear to be temperature, electrical conductance, ratio of nutrients, and $\mathrm{pH}$. In addition, greenhouse lettuce cultivars differ in their incidence of

Received for publication 3 May 1991. Accepted for publication 4 Feb. 1992. The investigation reported in this paper (no. 91-10-75) is in connection with a project of the Kentucky Agricultural Experiment Station and is published with approval of the Director. We appreciate the technical assistance of Roselee Harmon, Donna Switzer, Dean Knavel, and James Crutchfield. This material is based on work supported by the U.S. Dept. of Agriculture (USDA), Cooperative State Research Service, under agreement nos. 86-CRSR-2-2864 and 88-34262-3419. Any findings, conclusions, or recommendations expressed in this publication are those of the authors and do not necessarily reflect the views of the USDA. The cost of publishing this paper was defrayed in part by the payment of page charges. Under postal regulations, this paper therefore must be hereby marked $a d$ vertisement solely to indicate this fact.

'Present address: Dept. of Horticultural Plant Nutrition, Univ. of Agriculture, Dabrowskiego 169, 60-594 Poznan, Poland. tipburn when grown under standard greenhouse production practices (Cox and McKee, 1976).

Although very little information is available regarding the influence of $\mathrm{K}$ concentration on incidence of tipburn in NFT-produced lettuce, Borkowski and Ostrzycka's (1973) findings suggest that increased $\mathrm{K}$ availability increases incidence of tipburn injury in greenhouse-grown potted lettuce. Additionally, to our knowledge, the influence of solution $\mathrm{pH}$ in soilless culture on lettuce tipburn has not been investigated. Information reported usually concerns the $\mathrm{pH}$ optimum for crop growth (Douglas, 1985; Graves, 1983). The objectives of this study were thus to determine the influence of $\mathrm{K}$ level and $\mathrm{pH}$ of nutrient solution on the incidence of tipburn and yield of lettuce grown in NFT. The effect of $\mathrm{pH}$ on nutrient accumulation in lettuce was also evaluated.

Four NFT experiments were conducted in a greenhouse in Lexington, Ky. (Table 1). 'Summer Bibb' lettuce was used in Expt. 1; 'Summer Bibb', 'Buttercrunch', and 'Grand Rapids' in Expt. 2; and in Expts. 3 and 4 'Summer Bibb' and 'Buttercrunch' were evaluated. Lettuce seed was sown in individual Jiffy-9 peat pellets (Jiffy Products of America, Chicago), which were placed in a bottom-heated (28C) mist bench. At the first true-leaf stage, plants were moved to a bench with a capillary mat for subirrigation. Lettuce was irrigated once every $24 \mathrm{~h}$ with $0.2 \%$ Peter's Professional fertilizer solution (15N7P-14.2K) (Peters Fertilizer Products, W.R. Grace and Co., Fogelsville, Pa.) until seedlings reached the three to four true-leaf stage. The plants were grown thereafter in $7.5-\mathrm{cm}$ diameter polyvinylchloride gutters that were cut in half lengthwise. Within each gutter, up to nine transplants, spaced $20 \mathrm{~cm}$ apart, were set through holes in a polyethylene cover. Temperature and light conditions in the greenhouse varied with the season of production. Temperature generally ranged from 23 to $30 \mathrm{C}$ during the day and 18 to $24 \mathrm{C}$ at night.

The composition of the nutrient solution used for NFT production was (mg.liter ${ }^{-1}$ ): N, 140; P, 60; Ca, 150; Mg, 40; Fe, 2; Mn, 0.5; Cu, 0.05; Zn, 0.1; B, 0.3; Mo, 0.04; and K, 150 or 225 (Willumsen, 1984). In Expts. 1 and 2, the factorial design consisted of two concentrations of K (150 and 225 $\left.\mathrm{mg} \cdot \mathrm{liter}^{-1}\right)$ and four $\mathrm{pH}$ levels (5.0, 5.5, 6.0, and 6.5). Treatments were replicated three times and arranged in a randomized complete-block design with nine plants per experimental unit in Expt. 1 and four plants per unit in Expt. 2. Based on the results of Expts. 1 and 2, one level of $\mathrm{K}\left(150 \mathrm{mg} \cdot\right.$ liter $\left.^{-1}\right)$ and four levels of $\mathrm{pH}$ were investigated in Expts. 3 and 4 . Experiments 3 and 4 were also replicated as a randomized completeblock design with cultivar and $\mathrm{pH}$ level as factors; each experimental unit consisted of eight plants. Based on ambient temperature and plant size, solutions were recirculated with pumping from six to 14 times each 24 $\mathrm{h}$ for $20 \mathrm{~min}$ for each recirculation at the rate of 1 liter of solution/minute per trough. A standard solution volume of 1.8 liters was available for each plant in each experiment.

Table 1. Dates for sowing, treatment initiation, and termination for studies conducted with lettuce grown with the nutrient film technique in greenhouses.

\begin{tabular}{|c|c|c|c|}
\hline \multirow[b]{2}{*}{ Action } & \multicolumn{3}{|c|}{ Expts. } \\
\hline & 2 & 3 & 4 \\
\hline $\begin{array}{l}\text { Sowing date } \\
\text { Treatment }\end{array}$ & 3 Apr. 11 May & 20 Aug. & 4 Oct. \\
\hline $\begin{array}{l}\text { initiation } \\
\text { Experiment } \\
\text { termination }\end{array}$ & 16 May 15 June & $\mathrm{t}$ & 200 \\
\hline
\end{tabular}

Table 2. Incidence of tipburn injury in lettuce at $150 \mathrm{mg} \mathrm{K} / \mathrm{liter}$ and four $\mathrm{pH}$ levels.

\begin{tabular}{lccc}
\hline \hline & & \multicolumn{2}{c}{ Expt. } \\
\cline { 3 - 4 } Cultivar & $\mathrm{pH}$ & 3 & 4 \\
\hline Summer Bibb & 5.0 & 12.5 & 16.7 \\
& 5.5 & 20.8 & 8.3 \\
& 6.0 & 20.8 & 4.2 \\
& 6.5 & 25.0 & 4.2 \\
Significance & & & \\
$\quad$ Linear & & $*$ & $*$ \\
Quadratic & & $*$ & NS \\
Buttercrunch & 5.0 & 45.8 & 37.5 \\
& 5.5 & 75.0 & 41.2 \\
& 6.0 & 100.0 & 33.3 \\
Significance & 6.5 & 75.0 & 16.7 \\
$\quad$ Linear & & & \\
Quadratic & & NS & NS \\
\hline
\end{tabular}

zTipburn injury was rated visually at the end of the experiment by estimating the percentage of plants exhibiting tipburn injury at 32 and 30 days after the start of the experment for Expts. 3 and 4 , respectively.

NS.* Nonsignificant or significant at $P=0.05$. 
Table 3. Foliar content (percent) of $\mathrm{NO}_{3}-\mathrm{N}$ and total $\mathrm{N}, \mathrm{P}, \mathrm{K} \mathrm{Ca}, \mathrm{Mg}$, and $\mathrm{Na}$ in lettuce produced by the nutrient film technique in Expt. 3.

\begin{tabular}{lccccccc}
\hline \hline & \multicolumn{7}{c}{ Nutrients (\%) } \\
\cline { 2 - 8 } Variable & $\mathrm{NO}_{3}$-N & $\mathrm{N}$ & $\mathrm{P}$ & $\mathrm{K}$ & $\mathrm{Ca}$ & $\mathrm{Mg}$ & $\mathrm{Na}$ \\
\hline Cultivar & & & & & & & \\
$\quad$ Buttercrunch & 0.81 & 5.32 & 0.87 & 7.26 & 1.16 & 0.30 & 0.032 \\
$\quad$ Summer Bibb & 1.20 & 5.69 & 1.03 & 7.67 & 1.58 & 0.42 & 0.037 \\
LSD (0.05) & 0.06 & 0.14 & 0.03 & 0.13 & 0.03 & 0.01 & 0.003 \\
pH & & & & & & & \\
5.0 & 0.95 & 5.53 & 0.98 & 7.34 & 1.42 & 0.39 & 0.009 \\
5.5 & 0.97 & 5.45 & 0.93 & 7.37 & 1.36 & 0.37 & 0.014 \\
6.0 & 1.05 & 5.50 & 0.97 & 7.50 & 1.36 & 0.35 & 0.036 \\
6.5 & 1.04 & 5.53 & 0.92 & 7.64 & 1.33 & 0.34 & 0.078 \\
LSD (0.05) & 0.08 & 0.19 & 0.04 & 0.19 & 0.05 & 0.02 & 0.004 \\
Significance & & & & & & & \\
Cultivar & $* * *$ & $* * *$ & $* * *$ & $* * *$ & $* * *$ & $* * *$ & $* * *$ \\
pH & & & & & & & \\
$\quad$ Linear & $*$ & NS & $*$ & $* *$ & $* *$ & $* * *$ & $* * *$ \\
$\quad$ Quadratic & NS & NS & NS & NS & NS & NS & $* * *$ \\
Cultivar $\times$ pH & NS & NS & NS & NS & NS & NS & $* *$ \\
\hline
\end{tabular}

NS,*,**,***Nonsignificant or significant at $P=0.05,0.01$, or 0.001 , respectively.

Table 4. Foliar content (percent) of $\mathrm{NO}_{3}-\mathrm{N}$ and total $\mathrm{N}, \mathrm{P}, \mathrm{K}, \mathrm{Ca}, \mathrm{Mg}$, and $\mathrm{Na}$ in lettuce produced by the nutrient film technique in Expt. 4.

\begin{tabular}{|c|c|c|c|c|c|c|c|}
\hline \multirow[b]{2}{*}{ Variable } & \multicolumn{7}{|c|}{ Nutrients (\%) } \\
\hline & $\mathrm{NO}_{3}-\mathrm{N}$ & $\mathrm{N}$ & $\mathrm{P}$ & $\mathbf{K}$ & $\mathrm{Ca}$ & $\mathrm{Mg}$ & $\mathrm{Na}$ \\
\hline \multicolumn{8}{|l|}{ Cultivar } \\
\hline Buttercrunch & 1.37 & 5.72 & 1.00 & 8.10 & 1.47 & 0.41 & 0.136 \\
\hline Summer Bibb & 1.65 & 6.14 & 1.41 & 7.93 & 1.89 & 0.53 & 0.119 \\
\hline LSD $(0.05)$ & 0.07 & 0.09 & 0.04 & 0.16 & 0.05 & 0.01 & 0.005 \\
\hline \multicolumn{8}{|l|}{$\mathrm{pH}$} \\
\hline 5.0 & 1.43 & 5.88 & 1.18 & 7.49 & 1.62 & 0.46 & 0.49 \\
\hline 5.5 & 1.50 & 5.95 & 1.24 & 8.04 & 1.72 & 0.49 & 0.90 \\
\hline 6.0 & 1.55 & 6.03 & 1.26 & 8.24 & 1.70 & 0.47 & 0.142 \\
\hline 6.5 & 1.55 & 5.88 & 1.15 & 8.29 & 1.67 & 0.46 & 0.228 \\
\hline LSD $(0.05)$ & 0.09 & 0.12 & 0.05 & 0.22 & 0.07 & 0.02 & 0.007 \\
\hline \multicolumn{8}{|l|}{ Significance } \\
\hline Cultivar & *** & $* * *$ & $* * *$ & * & $* * *$ & $* * *$ & $* * *$ \\
\hline \multicolumn{8}{|l|}{$\mathrm{pH}$} \\
\hline Linear & ** & NS & NS & $* * *$ & NS & NS & $* * *$ \\
\hline Quadratic & NS & $*$ & $* * *$ & ** & * & $* *$ & $* * *$ \\
\hline Cultivar $\times \mathrm{pH}$ & NS & NS & $*$ & NS & NS & NS & NS \\
\hline
\end{tabular}

Ns,*,******Nonsignificant or significant at $P=0.05,0.01$, or 0.001 , respectively.

The solution drained from the trough between pumpings. The solution $\mathrm{pH}$ was adjusted daily, using $1 \mathrm{~m} \mathrm{NaOH}$ or $1 \mathrm{M} \mathrm{HCI}$, and solutions were replaced weekly. Solution $\mathrm{pH}$ was generally quite stable for all treatments, with $\mathrm{pH}$ variations of less than $5 \%$ above or below selected values. Potassium concentrations did not vary more than $10 \%$ from selected values during experimentation.

During experiments, the general appearance and incidence of tipburn was observed for each individual head of lettuce. Fresh weight and the percentage of plants showing tipburn were determined at the conclusion of each experiment. Based on results for Expts. 1 and 2, more detailed investigations were performed in Expts. 3 and 4. In Expts. 3 and 4, six leaf samples were randomly selected from the plants within each treatment for chemical analysis. The samples were washed, oven-dried at 50C, and pulverized. Total $\mathrm{N}$ (micro-Kjeldahl); total P (colorimetry); total $\mathrm{K}, \mathrm{Ca}, \mathrm{Mg}$, and $\mathrm{Na}$ (atomic absorption spectrometry); and water-soluble nitrate (photocolorimetric method) were analyzed. The content of elements was expressed as a percentage of dried matter.

Data were subjected to analysis of variance and regression, or trend analysis was used where appropriate. A slope comparison test was used to compare cultivar yield response over $\mathrm{pH}$ levels. Means were separated by Fisher's protected LSD (0.05).

Between $70 \%$ and $100 \%$ of 'Summer Bibb' and 'Buttercrunch' plants in Expts. 1 and 2 developed tipburn in all $\mathrm{pH}$ solutions and $\mathrm{K}$ treatments. Tipburn was observed as early as 5 to 6 days after plants were placed in NFT solutions in these experiments, with increasing tipburn incidence occurring until harvest at 21 or 16 days. Tipburn incidence in 'Summer Bibb' or 'Buttercrunch' lettuce was not significantly influenced by solution $\mathrm{pH}$ level or K concentration (data not shown). No tipburn was observed in 'Grand Rapids' lettuce in any solution for the duration of the experiment. 'Grand Rapids' was previously reported to be resistant to tipburn (Schlagnhaufer et al., 1987) and was included in our experimentation for comparative purposes.

In Expts. 3 and 4, 'Summer Bibb' lettuce generally exhibited from $30 \%$ to $50 \%$ lower incidence of tipburn than did 'Buttercrunch' (Table 2). The initial symptoms of tipburn injury were observed at about the same time in each treatment (between 20 and 30 days). Solution $\mathrm{pH}$ did have a significant influence on tipburn injury observed, particularly in 'Summer Bibb' lettuce, but this $\mathrm{pH}$ trend effect was not consistent among experiments. In Expt. 3, the percentage of plants exhibiting tipburn increased slightly with increasing $\mathrm{pH}$, while the percentage decreased in Expt. 4. When analyzed over cultivar, cultivar $\times \mathrm{pH}$ interactions were not significant in Expts. 3 or 4 (data not presented). The results obtained in all experiments suggest that tipburn injury is primarily controlled by genetic factors and is influenced by environmental conditions maintained during growth, with greater incidence of tipburn observed in greenhouse experiments conducted during the long, warm days of spring and summer.

Differences in K concentrations generally did not have a major influence on 'Summer Bibb' and 'Buttercrunch' lettuce fresh weight after 21 or 16 days of growth in NFT solutions in Expts. 1 and 2, respectively (data not presented). Significant differences were observed only in Expt. 2, when the fresh weight of 'Grand Rapids' plants produced at $150 \mathrm{mg} \mathrm{K} /$ liter was higher than that produced at $225 \mathrm{mg} \mathrm{K} /$ liter. The effect of $\mathrm{pH}$ on lettuce fresh weight was also minimal. With 'Buttercrunch', the highest fresh weight $(75 \mathrm{~g} /$ plant) was observed at $\mathrm{pH} 6.5$ and $150 \mathrm{mg}$ $\mathrm{K} /$ liter, as compared to $65 \mathrm{~g} / \mathrm{plant}$ at $225 \mathrm{mg}$ $\mathrm{K} /$ liter. There were no significant interactions between $\mathrm{K}$ level and $\mathrm{pH}$ for lettuce fresh weight in Expts. 1 and 2.

Since K level generally had no significant effect on incidence of tipburn and plant growth in NFT lettuce, only the lower K concentration (150 mg.liter $\left.{ }^{-1}\right)$ was used in Expts. 3 and 4. In Expt. 3, lettuce fresh weight accumulation was not influenced by either solution $\mathrm{pH}$ or cultivar ('Summer Bibb' and 'Buttercrunch') during the 25 days in NFT culture. Lettuce fresh weight ranged from 41.8 to $44.9 \mathrm{~g}$ among cultivars and solution pH treatments. In Expt. 4, pH had a minimally significant influence on yield, with lettuce fresh weight increasing as $\mathrm{pH}$ increased (Fig. 1). Both cultivars exhibited nearly equivalent increases in yield with increasing $\mathrm{pH}$ levels as measured by a slope comparison test, indicating no cultivar differences in response.

According to Willumsen (1984), different ratios of $\mathrm{K}, \mathrm{Ca}$, and $\mathrm{Mg}$ maintained in NFT solution had no influence on lettuce tipburn development and did not result in any significant yield differences. In field experiments, Collier and Huntington (1980) showed that lettuce grown on acidified plots $(\mathrm{pH} 5.5)$ did not consistently develop more tipburn than plants grown at $\mathrm{pH}$ 6.6. A high ratio of $\mathrm{K}$ fertilizer also did not enhance tipburn occurrence. Similarly, our studies indicate that, in NFT culture, neither K level nor $\mathrm{pH}$ level strongly affect the incidence of tipburn in several lettuce cultivars. Conversely, Bor- 


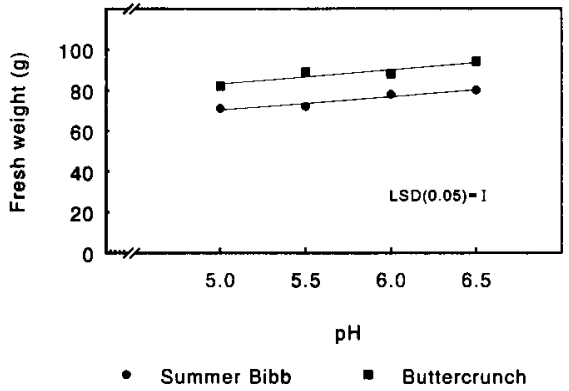

Fig. 1. Influence of $\mathrm{pH}$ level on fresh weight of 'Summer Bibb' and 'Buttercrunch' lettuce at 150 $\mathrm{mg} \mathrm{K} / \mathrm{liter}$ in Expt. 4. The regression equation for 'Summer Bibb' yield response over $\mathrm{pH}$ level is $\mathrm{Y}=37.30+6.6 \mathrm{x}$. The regression equation for 'Buttercrunch' yield response over $\mathrm{pH}$ level is $\mathrm{Y}=48.00+7.00 \mathrm{x}$.

kowski and Ostrzycka (1973) reported that the addition of $\mathrm{K}$ increased the susceptibility of lettuce to tipburn injury in greenhouse pot investigations. It may be that higher concentrations of $\mathrm{K}$ in the growth medium reduced root pressure and the ability of potted lettuce to take up water, inducing greater tipburn incidence (Van den Ende et al., 1975).

Accumulation of $\mathrm{NO}_{3}-\mathrm{N}$ and total $\mathrm{N}, \mathrm{P}$, $\mathrm{Ca}, \mathrm{Mg}$, and $\mathrm{Na}$ was significantly higher $(P=0.001)$ in 'Summer Bibb' than in 'Buttercrunch' lettuce (Tables 3 and 4), indicating cultivar differences in nutrient accumulation. The reduced levels of $\mathrm{Ca}$ accumulation in 'Buttercrunch' lettuce may contribute to the increased incidence of tipburn observed in this cultivar over time, possibly due to enhanced sensitivity of this cultivar to unfavorable environmental conditions that resulted in reduced $\mathrm{Ca}$ levels in young lettuce leaves (Collier and Tibbitts, 1982, 1984). The $\mathrm{pH}$ level did not affect concentration of total $\mathrm{N}$ or $\mathrm{NO}_{3}-\mathrm{N}$, although a slight increase in NQ-N was observed with increasing $\mathrm{pH}$ in both experiments. Similar conclusions were obtained by Vassey et al. (1990) in soybean [Glycine max (L.) Merr.]. Increasing $\mathrm{pH}$ levels resulted in a linear or quadratic increase in $\mathrm{K}$ accumulation in lettuce in Expts. 3 and 4. Islam et al. (1980) also obtained the same trend in hydroponically grown tomatoes (Lycopersicon esculentum Mill.). Although the influence of solution $\mathrm{pH}$ on $\mathrm{P}, \mathrm{Ca}$, and $\mathrm{Mg}$ concentration was significant, differences in nutrient accumulation were generally not great and were not reflected in lettuce fresh weight differences. Significant influence of $\mathrm{pH}$ on $\mathrm{Na}$ accumulation was related to the amount of $\mathrm{NaOH}$ used to maintain constant $\mathrm{pH}$ of nutrient solutions, with greater $\mathrm{NaOH}$ addition with increasing $\mathrm{pH}$ level. The suggestion that increased $\mathrm{Na}$ availability can increase the incidence of tipburn in lettuce (Sonneveld and Ende, 1975) was not confirmed in these experiments, particularly since the $\mathrm{Na}$ levels used were considerably lower than those investigated by Sonnevald and Ende. There were no significant interactions between cultivars and $\mathrm{pH}$ levels for $\mathrm{NO}_{3}-\mathrm{N}$ and total $\mathrm{N}$, $\mathrm{K}, \mathrm{Ca}$, and $\mathrm{Mg}$.

In conclusion, $\mathrm{K}$ provided at $150 \mathrm{mg} \cdot \mathrm{liter}^{-1}$ in solution was found to be sufficient for NFT lettuce production in these experiments. Potassium concentration did not significantly influence tipburn incidence in the three lettuce cultivars examined. 'Summer Bibb' and 'Buttercrunch' lettuce were tolerant of solution $\mathrm{pH}$ in the range of 5.0 to 6.5. The influence of $\mathrm{pH}$ on tipburn incidence and nutrient accumulation in lettuce was also limited. To significantly reduce tipburn damage in lettuce, a tolerant cultivar, such as 'Grand Rapids', should be used rather than adjustment of $\mathrm{pH}$ or $\mathrm{K}$ levels in NFT culture. In addition, environmental control of greenhouse temperatures, light intensity and duration, and relative humidity should also be practiced (Collier and Tibbitts, 1982, 1984).

\section{Literature Cited}

Borkowski, J. and J. Ostrzycka. 1973. The control of blossom-end rot of tomato and tipburn in lettuce by using the proper fertilization. Acta Hort. 29:327-339.
Collier, G.F. and V.C. Huntington. 1980. Influence of $\mathrm{pH}$ and potassium on-physiological disorders. Natl. Veg. Res. Sta.. Wellesbourne Warwick, England. Rpt. 30:112-113.

Collier, G.F. and T.W. Tibbitts. 1982. Tipburn in lettuce. Hort. Rev. 4:49-65.

Collier, G.F. and T.W. Tibbitts. 1984. Effects of relative humidity and root temperature on calcium concentration and tipburn development in lettuce. J. Amer. Soc. Hort. Sci. 109(2):128131.

Cox, E.F. and J.M.T. McKee. 1976. A comparison of tipburn susceptibility in lettuce under field and glasshouse conditions. J. Hort. Sci. 51:117-122.

Douglas, J.S. 1985. Advanced guide to hydroponics. Pelham Books, London.

Graves, C.H. 1983. The-nutrient film technique. Hort. Rev. 5:1-44.

Islam, A.K.M.S., D.G. Edwards, and C.J. Asher. 1980. $\mathrm{pH}$ optima for crop growth. Results of a flowering solution culture experiment with six species. Plant Soil 54:339-357.

Schlagnhaufer, B.E., E.J. Holcomb, and M.D. Orzolek. 1987. Effect of supplementary light, solution heating, and increased solution $\mathrm{Ca}$ levels on lettuce production in the nutrient technique. Applied Agr. Res. 2(2):124-129.

Sonneveld, C. and J. van den Ende. 1975. The effects of some salts and head weight and tipburn development in lettuce and on fruit production and blossom-end rot of tomatoes. Neth. J. Agr. Sci. 23:191-201.

Tibbitts, T.W. and R.R. Rao. 1966. Light intensity and duration in the development of lettuce tipburn. Proc. Amer. Soc. Hort. Sci. 93:454461.

Van den Ende, J., P. Koomneef, and C. Sonnevelde. 1975. Osmotic pressure of the soil solution: Determination and effects on some glasshouse crops. Neth. J. Agr. Sci. 23:181190

Vessey, J.K., L.T. Henry, S. Chaillou, and C.D. Raper, Jr. 1990. Root-zone acidity affects relative uptake of nitrate and ammonium from mixed nitrogen sources. J. Plant Nutr. 13:95116.

Willumsen, J. 1984. Nutritional requirements of lettuce in water culture. Intl. Soc. Soilless Culture. Proc. 6th Intl. Congr. on Soilless Culture, Luntern. p. 771-791. 